HStud 22 (2008) 1-2, 63-76

DOI: 10.15566/HStud.22.2008.1-2.5

\title{
IF THE TUNE IS JEWISH, WHY IS THE STYLE HUNGARIAN?
}

\author{
JOSHUA HOROWITZ
}

Madison, CT

USA

\begin{abstract}
Within the past fifteen years, the klezmer (East European instrumental Jewish Music) music scene has included music of Transylvania (usually Kalotaszeg) that is stylistically specific to that region, even when the tunes played are considered Jewish. Popular groups such as Muzsikás and Di Naye Kapelye have circulated and popularized a limited standard repertoire, which has served partially to redefine what were formerly considered the elements of klezmer style. Motivations for the dissemination of this sub-trend are at the same time musical, commercial, academic and ideological. The needs of presenters and venues to vary their music programs has further aided in the dissemination of the sub-trend. The results have inspired some participants of klezmer music to observe what makes their music ethnically specific and to critically re-examine the tenets on which historical assumptions are made.
\end{abstract}

Keywords: Klezmer, dance house, táncház, folklore revival, folk music, Transylvania, Hungarian, East European instrumental Jewish music, Jewish style, Kalotaszeg, Muzsikás, Di Naye Kapelye, sub-trend

Since the mid 1990s music has been introduced into the Klezmer scene from the regions of Maramureș and Kalotaszeg. ${ }^{1}$ Following the lead of the Táncház ${ }^{2}$ (dance house) Movement of Hungary, first non-Jews, then later Jews began to redefine what were formerly considered the stylistic and repertoire parameters of Klezmer music. If we contextualize these processes historically and then pose questions as to what is accurate in the relationship between the promotion and actual content of the promotion of the participants involved, we can come closer to an understanding of their function in both the Klezmer and dance house scenes. The development of the dance house movement and the Klezmer Revival ${ }^{3}$ took place independently of each other, respectively in the early and late 1970s, specifically 1972 for the dance house and ca. 1976 for Klezmer. Common to both scenes at the outset was the motivation to preserve, revive and perform folk music of certain areas and ethnicities. But these movements, or scenes, differed at that time in their methods and sources. 
The early era of the dance house movement focused first on the style of music from the Mezőség region, ${ }^{4}$ specifically from Szék. ${ }^{5}$ The second style that came to be integrated into the dance house scene was from the region of Kalotaszeg, which is more cosmopolitan, with influences from the city. The harmonic rhythm is typically quite dense, with frequent changes of harmony to support the melody. ${ }^{6}$ The early era of the American Klezmer Revival ${ }^{7}$ focused on the other hand on the core Klezmer repertoire as found on early 78 r.p.m. recordings issued in the USA primarily by immigrants, roughly from 1911-1942. Although the Israeli Hasidic clarinetist Moussa Berlin was learning Klezmer tunes from early 78 r.p.m. recordings of Dave Tarras and Naftule Brandwein in the 1960s, the American Klezmer revival got its start in the mid 1970s with the work of The Klezmorim, Andy Statman and Zev Feldman, and Kapelye, then later The Klezmer Conservatory Band and Brave Old World.

The groups featured on the early records were predominantly from the areas of the Russian Empire where Jews settled, known as the Pale of Settlement, especially what is today western Ukraine. Their styles and repertoire are remarkably uniform in many details, despite the geographic spread of the regions. The styles that came to define the earliest of the revival groups were based more or less on these styles, but the more traditional styles were soon supplanted by groups coming after the above-mentioned ensembles, with their aesthetic shaped by American music, such as swing and the New York brands of Yiddish Theater. The more traditional stylistic elements that came to define the Klezmer Revival were those found east of Transylvania and did not seem to encompass any of the styles that came to define the dance house movement; the styles of Maramureș, Mezőség and Kalotaszeg are entirely absent.

\section{Similarities between the Dance House and Klezmer Movements}

- Educated urban-dwellers, most notably in Budapest and New York, have propagated both scenes. Many of the musicians have been active in other genres of music, such as jazz and various types of folk, classical and rock music.

- Both scenes have sought to and succeeded in integrating three generations of audience members and participants.

- Both scenes have developed camps and festivals, not only in Budapest and New York, but worldwide. 


\section{Differences between the Dance House and Klezmer Movements}

- From the outset, dance house has relied heavily on informants for repertoire and style, whereas Klezmer has relied primarily on commercially issued early 78 r.p.m. recordings.

- The dance house movement has worked with and received information from ethnicities which themselves were not geographically displaced (although the regions fell under Hungarian and then Romanian rule), whereas the majority of the early Klezmer musicians of the 78 r.p.m. recordings were immigrants who were displaced to America, so their original style and repertoire developed thousands of miles away on foreign soil.

- The dance house proponents distinguished between village and city music, especially Mezőség and Kalotaszeg, and later Carpathian and Jewish music, whereas Klezmer musicians developed urban music (Jewish village music was rarely if ever recorded commercially) with little attention to the question of urban and rural styles.

- The dance house movement emphasized interaction with informants professionally, whereas Klezmer musicians have had few informants with whom they could interact. ${ }^{8}$

- In its early stages the dance house movement exhibited an element of protest against state-sanctioned culture, whereas the Klezmer Revival developed in an atmosphere free of state artistic control.

- The dance house movement included dance from the outset (as implied by its name), whereas the Klezmer scene integrated dance only later in its development, most notably since the 1990 s.

\section{Ten Stylistic Characteristics of Dance House and Klezmer}

\section{Dance House}

- Düvö technique - undulating, often asymmetric legato bowing technique

- Apraja - high connecting phrases between tunes

- Chaining - fluid connection of dance tunes or sections

- String-based music, including 3-string basses, violas, cimbaloms

- String based esztam (contra offbeats ${ }^{9}$ )

- Sophisticated harmonic techniques, including major chords over minor tonalities (usually on $1^{\text {st }}$ and $4^{\text {th }}$ degrees), bVI chords moving to $\mathrm{V}$ chords, and frequent use of $\mathrm{V} 7$ chords

- Formalized cadences specific to the genre of the tune

- Short-long melodic phrasing of groups of dotted eighth-sixteenth notes 
- Pronounced wide violin vibrato

- Less use of Freygish (DEbF\#GABbCD) and Yishtebach (DEbFGAbBCD) modes

Klezmer

- Bulgar pattern $(3+3+2)$ forms the basis of the backbeat of faster duple meter dance tunes

- Vamps connecting slow tunes with fast tunes

- Clarinet and Brass based music

- Simple harmonization, often influenced by jazz

- Formalized cadences specific to the genre and mode of the tune

- Clipped 2-note phrasing articulation of sixteenth note groupings of four notes

- Pronounced use of Freygish (DEbF\#GABbCD), Yishtebach (DEbFGAbBCD) and Mishebarakh, or Ukrainian Dorian modes (DEFG\#ABCD)

- Pre-war Klezmer music is typically simply harmonized, often with one implied or stated harmony serving for entire sections regardless of implied modal changes

- Violin "sweet sound" using vocal gestures of the synagogue

- Use of Krekhts (sobbing escape tone)

\section{Historical Background of Jewish Music in Maramureș}

Kaliver Hasidic Dynasty, Maramureș ${ }^{10}$

Jews living in Maramures from the time of the first Rabbi of Hungary in the early 19th century till the present day were predominantly Hasidic. Rabbi Yitzchak Isaac Taub from the Hasidic Kaliver Dynasty Kaliv (Kalov, Kalev, also Nagykálló) of Hungary, now northeastern Maramures, was known as the "Sweet Singer of Israel" (1744-1828). He composed many popular Hasidic melodies and often adapted Hungarian folk songs by substituting Jewish words for Hungarian ones. He was famous for composing the traditional Hungarian Hasidic tune, Szól a kakas már, ${ }^{11}$ as well as the tunes, Sirnak rinak a bárányok (Mournful bleat the sheep) and Erdö, erdö (Forest, forest). He taught that the tunes he heard were really from the Holy Temple in Jerusalem, and had been lost among the nations over the years until he found them and returned them to the Jewish people. He supported this claim by asserting that the Gentiles who taught him the songs soon forgot them as soon as the Rabbi learned them. 
Vishnitzer Hasidic Dynasty in Maramureș

Vishnitz, Bukovina Hasidim, who were ardent followers of Rabbi Israel Hager $(1860-1936)^{12}$ and the Szatmar Rabbi Chaim Tzvi Teitelbaum (1880-1926) settled in Maramureș. The brand of Hasidism that developed among the Vishnitzer Hasidim was of a folksy variety. They were mostly farmers and became well known for their melodies, which have been collected extensively in Israel. ${ }^{13}$ There were also tunes collected and published before the war. ${ }^{14}$

\section{Maramureș Jewish Instrumental Style}

While many of the tunes sung by the Maramureș Hasidim were and still are widespread among many Jewish and Hasidic communities to date, we know little about the instrumental style of the music. The tunes we have, which were at some point found to be part of the Maramures musical landscape, have a modal structure that does not deviate from what we know of Klezmer tunes today. They consist of the common Klezmer modes Freygish (scalar form: DEbF\#GABbCD), Ukrainian Dorian (scalar form: DEFG\#ABCD) and minor modes with occasional flatted 2nds in their cadences. Although the accompaniment of the Jewish music we know of from most of the regions of the Jewish Pale of Settlement east of the Carpathians is usually quite simple with accompanying harmonies that don't deviate from the mode, some of the examples we have of Gypsies performing Jewish music show Maramureș "indicators," such as a major chord used to accompany a minor melodic cadence. ${ }^{15}$

We know that The Kaliver Rabbi loved Hungarian music and co-opted many of its tunes. But did he also encourage the klezmorim to play those tunes with major harmonic accompaniments over minor melodies, such as we find today in the non-Jewish folk tunes of Maramureș? Based on the Kaliver Rabbi's need to redefine Hungarian tunes as Jewish, we could conjecture that he may have encouraged his musicians to make the style more Jewish, in the style of many of the Jewish tunes coming from the heartland Gubernias of the Pale of Settlement. However, even were we to find evidence of this, there is no longer any way to make a sampling large enough to draw substantive conclusions about "regional" Jewish instrumental styles in Maramureș. 


\section{Mukachevo $^{16}$}

There was a strong relationship between the Jewish communities of Maramureș and Mukachevo (Munkács), the latter of which was headed by Rabbi Chaim Elazar Spira. There is a rare historical film recording of the wedding of Rabbi Spira's daughter in 1933, in which a short military march was played, followed by a Khupe ${ }^{17}$ march in the Freygish mode. ${ }^{18}$ The musicians were probably from Galitsia and had played on the Hungarian side of the Carpathians, yet nothing in their playing hints at any of the Hungarian styles as we know them today. The style is typical to Klezmer music throughout the regions east of the Carpathians, through western Ukraine. There were three violins, a viola, a baraban (frame drum) and C-melody saxophone or alto saxophone.

\section{Bartók and Jewish Music}

Whereas for the most part the modern Klezmer scene from the 1970s to the present has used as its source material a corpus of less than 100078 r.p.m. recordings made by immigrants to America between 1911 and 1942, with only scattered notes concerning sources, the dance house scene has used field recordings, mostly modern, but also historical as their primary sources. Regarding the use of historical fieldwork, the question as to why Bartók did not include Jewish music in his research is important.

According to Judit Frigyesi, ${ }^{19}$ Bartók perceived there to be a chasm between the Hungarian countryside and the cosmopolitan musical life of Budapest, the latter which he considered to be predominantly German/Jewish. Yet in spite of his early perceptions concerning Jews, Bartók's first supportive audience came from Jewish circles, as many publishers, editors, and University professors in his milieu provided financial backing. Bartók's initial disillusionment about Jews was based on the feeling that Germans and Jews were an intrusion upon Hungarian life. When he came to Budapest, he expected the modern bourgeoisie to be Hungarian and Christian, but soon labeled German and Jewish. Despite his preconceptions about Jews, Bartók himself ran the danger of being stamped Jewish by the Nazis, and his publisher, Universal, asked him to issue a statement in which he avowed not to be of Jewish ancestry, but he refused.

In light of Bartók's omission of Jewish music as an integral part of his definition of folk music and the fact that the early dance house movement was primarily concerned with Hungarian music as it was found in the villages of Transylvania, it is understandable that Jewish music was left out of the original stages of the dance 
house movement. In addition, the Jewish communities of Transylvania and Maramureș did not have highly profiled dance traditions, as the Mezőség, Kalotaszeg and Maramureș regions did.

\section{"World Music" and Industry Pressure}

One of the factors contributing to the swift movement away from the traditional styles of Klezmer was the pressure exerted by the music industry itself. Beginning in the 1980s ethnic music became increasingly difficult to sell. Prior to 1987 ethnic music did in fact have followings, but record companies, broadcasters and journalists ${ }^{20}$ found it ever more difficult to reach larger and crossover audiences. At the meetings leading up to the first 1987 World Music Month of WOMAD $^{21}$ the most urgent concern was to select an umbrella name through which to sell "new" ethnic music. Suggestions included "World Beat" and the addition of prefixes such as "hot" or "tropical"22 to existing genre titles, but "World Music" 23 won after a show of hands. In spite of the fact that World Music came to denote ethnic music with modern developments, it also included traditional ethnic music. And although there was a continuing interest on the part of audiences in both traditional as well as modernized ethnic music, the pressure from labels, journalists and presenters was relentless for traditional groups to diversify their music. For example, the German record label, Tropical, published a credo on the internet which read as follows:

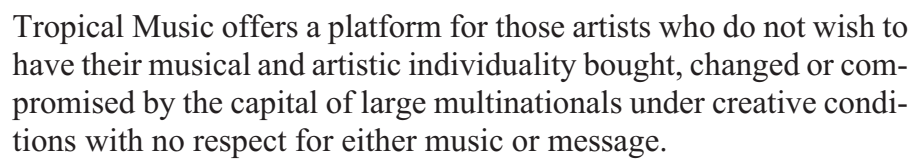
have their musical and artistic individuality bought, changed or compromised by the capital of large multinationals under creative conditions with no respect for either music or message.

In their contract negotiations however, the directive was quite the contrary:

Traditional music is very nice and we need it, but the world is moving on... can you make the product different? ... one may reach this by modernizing arrangements, adapting themes for different instrumentation [and] inviting guest soloists from other musical fields... ${ }^{24}$

\section{Muzsikás and "The Lost Jewish Music of Transylvania"}

The year after the WOMAD World Music Month, the group Muzsikás was invited to play Jewish music at a 1988 photo exhibition on Jewish religious life. At that time they were introduced to the Jewish musicologist and former student of 
Kodály, Zoltán Simon, who had carried out field research in Jewish music in Maramureș in 1946. They wrote,

When we asked him about the performing style, he explained that it was no different from the style of the Hungarian region, since the same group of musicians played for both Jewish and non-Jewish communities.

Muzsikás went out into the field to research their project, contacting Gypsies whose fathers had played for Jews before the war and who occasionally included them on gigs. Georghe (Cioata) Covaci and Toni Árpád remembered some of the tunes but admitted that they did not know the styles.

The field research of Muzsikás resulted in a broadening of the contributions of the dance house movement with their seminal 1993 CD, "Maramaros: The Lost Jewish Music of Transylvania," 25 with liner notes written by Professor Judit Frigyesi, a Hungarian born Jew presently working as Associate Professor at Bar Ilan University. ${ }^{26}$

\section{Marketing and the Spread of the Muzsikás Aesthetic}

But in spite of the title, which led buyers to believe that they are purchasing a newly discovered cultural treasure trove, the majority of the pieces on the record, while perhaps having fallen out of use in the regions of Transylvania through the destruction of the Jewish communities there, were not "lost" at all. In fact, most of the tunes on the record, for example Mayn SHTETELE Belz and Hat a Jid a Wejbele have remained staples in the Jewish musical landscape to this day. The melody to the prayer Ani Maamin is still performed in synagogues and by choirs and Klezmer bands across the globe, and continues to be sung on Holocaust Remembrance Day. There is also a tune on the CD, Haneros Halelu, which is culled directly from an important historical Klezmer reissue LP. ${ }^{27}$

Muzsikás was aware of the American Klezmer revival, and gave due credit in the liner notes to their sources. But in spite of the discrepancy between the title and the content of the $\mathrm{CD}$, promoters of their music and their recording pushed the idea of a "Jewish Atlantis". Here is an example of an advertisement for the $\mathrm{Mu}$ zsikás CD:

This exceptional album is the ancestor of Klezmer - the forgotten old Jewish music of the Carpathian Basin. Muzsikás has recorded these songs after years of research, collecting music from Gypsies, authentic players of Klezmer. ${ }^{28}$ 
Promoters followed suit. The album became the biggest all time seller of the Hannibal Record Label. ${ }^{29}$

The Toronto Ashkenaz Festival of 1995, the first and to this day still largest Jewish festival in North America, offered a program emphasizing groups with a modern bent, i.e., Jewish World Music. The three groups that filled the traditional slot were Brave Old World, Budowitz, and the freshly included Muzsikás with their "Lost Jewish Music" program. Muzsikás was treated as an archaeological find. In spite of the rainy weather, the packed audience at the outdoor Harbourfront Amphitheater braved the entire concert and went wild with enthusiasm. Much of the music on the Muzsikás program that evening was made up of Hungarian language songs and Kalotaszeg pieces, mixed with the Jewish pieces of the CD.

\section{So What's New?}

If the majority of the pieces on the Muzsikás CD were not "new" to those familiar with Jewish music, what was? In fact, the style of the pieces they played were perceived as unusual to those familiar with the typical Klezmer revival sound. Their group used a Gardon, ${ }^{30}$ a 3 -string viola, a small cimbalom, a gut-strung bass, a violin, a Turkish drum and featured a singer (Márta Sebestyén) who used ornamentation. The clarinet was missing and the instrumentation was string-based, something that Klezmer enthusiasts had read about but rarely if ever heard as being a common characteristic in Klezmer music before the advent of recording.

Since these pieces were in fact at one time actually played before the war in the regions where Muzsikás found them, their inclusion in the dance house context could be justified if needed. No further justification was needed in the Klezmer scene. The dances, however, were missing. Sue Foy, an American living in Budapest since the 1980s began to teach Jewish dances in and around Budapest.

\section{Di Naye Kapelye and the Inclusion of the Dance House Aesthetic}

In the mid 1990s, Bob Cohen, an American musician who moved to Budapest in the late 1980s, began playing violin with the Budapester Klezmer Band (now called the Budapest Klezmer Band), which claimed to be the "first Jewish band founded in Hungary since the Holocaust." 31 The Budapester Klezmer band was started in 1990 by Ferenc Jávori and modeled its early sound on the American versions of Klezmer tunes, as heard in Kapelye and The Klezmer Conservatory Band, but did not seem to be affected by the parallel developments happening underfoot in the dance house movement. Cohen left the Budapester Klezmer Band around 
1994 and began his own band, Di Naye Kapelye, (The New Band). Cohen was aware of the existence of the American Band, Kapelye. ${ }^{32}$

In the fall of 1995 Cohen and I went on a field trip to visit the informants cited on the Muzsikás record ${ }^{33}$ to find out if there were more Jewish tunes or tunes played for Jews. When I asked Béla Bácsi, the accordionist of Mera (Méra), Transylvania what he thought characterized Jewish style before the war, he said,

\begin{abstract}
It was simple, with only two chords. The Jewish contra players only used simple chords. But after the war when the accordion came around, it was easier to play more chords, so the accordion players put more chords to the tunes, and then the contra players started to play what the accordion players were playing.
\end{abstract}

Following the lead of the dance house movement, Cohen gradually began introducing first the tunes of the Muzsikás record, then other tunes that he had gotten from tapes from friends and from his own field recordings and eventually from the players themselves. ${ }^{34}$ Cohen's vocal performance style was modeled on Carpathian male village singers, and he would joke on stage about being distinguished as the loudest Jewish singer in the history of Jewish music. Like the promotion surrounding the Muzsikás project, Di Naye Kapelye's critiques and promotional material placed emphasis on the buzzwords "village," "roots," "authentic" and "tradition," both by the group itself and by journalists:

This is village-style Klezmer, foot-stomping, percussive, and earthy, played with gusto and brio. ${ }^{35}$

This is roots Klezmer in the best way, played in the style that would have had folks dancing madly all night a hundred years ago.... It is hard to imagine anyone else playing such a diversity of music, not only authentically, but with such heart and skill. ${ }^{36}$

\title{
Summary: Has There Been a Marriage of Dance House and Klezmer?
}

Since the advent of the Muzsikás CD and later, the sporadic contributions of Brave Old World and eventually Di Naye Kapelye, the Klezmer scene has witnessed scattered attempts to integrate versions of mostly Kalotaszeg and Maramures styles into the canon of the Klezmer repertoire. ${ }^{37}$ In addition, at the 2007 annual Klez Kamp ${ }^{38}$ gathering (the largest of its kind in the world) a new workshop was offered entitled "Carpathian Jewish Wedding Ensemble" in which the repertoire and style of the Covacis and the Muzsikás CD as well as various other dance house tunes were included in the context of Klezmer music. Recently the Técsői Banda (Tyachiv or Tetsh in Yiddish) has garnered interest in the dance 
house scene ${ }^{39}$ and their repertoire includes some little known Klezmer tunes as well as variants of familiar Klezmer tunes that have found their way into both the dance house and Klezmer repertoires.

Although it is tempting to view the connection of dance house and Klezmer as a trend, its propagation has been too limited on both sides to qualify it as such to date. While some repertoire has been introduced from each side to the other, it is too early to consider the interaction to be symbiotic. Rather, we could view the promotion of the early Muzsikás CD (with very little development since that time, however) and the recent works and promotion of Di Naye Kapelye, Jake Schulman-Ment, and some scattered groups in both the dance house and Klezmer scenes as an indication of an attempt to create a trend through the addition of tunes from each other's repertoires.

If we look at the pressures placed on the participants of both movements and their artistic motivations it would seem that the dance house scene has sought to increase and widen its stylistic parameters as well as its appeal in order to broaden its ethnic definitions and garner more interest in the traditional music of the regions with which they have dealt. On the Klezmer side, the motivations are similar, with the added need to redefine Klezmer music as including rural music, which in the absence of documents that would reveal how these traditions sounded, uses the dance house styles and model as its foundation.

\section{Notes}

In 1908 Dezső Malonyay edited a volume of art entitled Kalotaszeg, Art of the Hungarian People. It introduced the concept of "folk art" into Hungarian public awareness. In the first part of the 20th Century, the Carpathian Society of Transylvania, which funded the Museum of Ethnography in Budapest and the Ethnographic Museum in Cluj (Kolozsvár) featured the majority of its articles from the Kalotaszeg region. Béla Bartók and Béla Vikár were fascinated by the music of the region and collected folk music there.

2 The term dance house is derived from a Transylvanian tradition of holding dances in private homes. Since the 1970s Hungarians have been researching the music and culture of ethnic Hungarians outside of Hungary, such as those in Transylvania, Slovakia, and the Siret River valley of Moldavia.

3 The term Klezmer Revival refers specifically to the movement created first in the USA beginning around 1976 which promoted interest in East European Jewish instrumental music as a genre. By the 1980s klezmer bands performing in Europe, such as The Klezmorim, Kapelye and later Brave Old World, inspired dramatic growth in the interest of young European musicians in learning klezmer music. The movement is characterized by an initial interest in the styles of the 78 r.p.m. recordings, mostly produced in the U.S. between 1916-1942. The term implies a type of resurrection, though it should be noted that Klezmer music did not actually "die" prior to this period, although the 78 r.p.m. styles and instrumentation did in fact change later on American soil. 
4 Mezőség or Câmpia Transilvaniei is an ethno-geographical area in Transylvania located between the Someș and Mureș Rivers.

5 The area of Szék has three main roads. The marriages in Szék typically joined families living on the same street. There were often family feuds with families on the other streets. It is an isolated region, as the city ends at the mountains, so the only way to get beyond it is over the mountain by foot. The first collections in Szék were performed in the 1940s by László Lajtha. The Szék style is partially characterized by simple chords with limited use of changing harmonies and formed the first style of the dance house movement, led first by Zoltán Kallós (singer and music collector, Cluj) and György Martin (dance pedagogue, Budapest). The most venerable performer in Szék was István Ádám [Icsán], whose violin style was rough and pronounced. István has been jokingly called the Mezőség "hard rocker" due to the prevalence of I, IV and V major chords in his style.

6 The reason given to me for the use of extended harmonies by Béla Bácsi, the accordionist from Mera, Transylvania, was that the accordion was taken on by the Hungarians when they served in the Russian army in World War II. The left hand buttons of the accordion enabled easily created harmonies that could also be changed quickly. Therefore, the number of harmonies as well as the harmonic rhythm influenced the accompaniment of the music, and the main string instrument to play chords was the viola, which took on these characteristics.

7 Often, revivalist tendencies skip a generation: immigrants hold on to their traditions; the children of immigrants distance themselves from traditions. The grandchildren of immigrants may return to the traditions. Even if we consider the Klezmer revival to be based on "traditional sources," the end product of their styles quickly departed from a parroting of the styles on the records to more modernized and personalized versions. Aside from the early works of the Klezmorim, Andy Statman and Zev Feldman, and Kapelye, the period from around 1980 to 1992 did not yield many new works striving after the traditional except Brave Old World, Rubin \& Horowitz and later Budowitz.

8 Learning music directly from informants did however occur. Michael Alpert and Stuart Brotman learned from Ben Bazyler and Leon Schwartz, Andy Statman and Zev Feldman learned from Dave Tarras. I learned from Majer Bogdanski, Leopold Koslowski and Yermye Hescheles and Cookie Segelstein learned from members of her family from Veretski (Verecke) and Mukachevo. But the bulk of the tunes and their styles came from records.

9 The term contra or kontra usually refers to the 3-string viola, which has its bridge filed down flat to enable easy bowing of chords, but is also used to indicate the style of playing offbeat chords.

10 If we compare the delivery of Szól a kakas már as sung by Rabbi Menachem Mendel Taub, who is the sixth generation descendant of Rabbi Yitzchak Isaac of Kaliv, with that of Márta Sebestyén and Muzsikás we notice differences in style. First, the context of the Taub version is for a Hasidic gathering and is used as a prayer, while the Sebestyén version is for a CD and is used as folk art. The a capella version sung by Taub uses free rubato, while the Sebestyén version is stricter and aesthetically harmonized, with instrumental interludes. Also, Hasidism forbids the use of the female voice in prayer with men.

11 Hager eventually moved his court to Oradea in Transylvania, within easy access of Maramureș. His sons established themselves as the Rabbis in the Maramureș towns of Viș eul de Sus and Vilchovice.

12 During World War I sizeable Hasidic communities flourished in the areas of Sighetul Maramureș, Satu Mare, Mukachevo, Oradea, Carei Mare, Beregovo, Uzhgorod, Viș eul de Sus, Khust and their vicinities. The Hasidic courts were headed by the following Rabbis: Teitelbaum (Sziget-Szatmár), Sapinka (Weisz) and Spira (Mukachevo). 
13 In 1938, the conductor of the Opera and of the Goldmark Symphony Orchestra in Cluj, Alexander Boskovitch (1907-1964), called for the collection and preservation of the music of the Jews of Hungary, Romania and Transylvania, inspiring Max Eiskovits, a musicology student and later harmony and counterpoint professor at the University of Cluj, to collect and publish the niggunim of the Hasidic Jews of Maramureș, some of which eventually found their way into the 1980 publication, Songs of the Martyrs.

14 We have some untitled recordings of the musicologist, Harry Brauner from the 1970s of alleged Gypsy musicians performing a Jewish March and Doina on violin with string accompaniment.

15 The city of Mukachevo was part of the Kingdom of Hungary from 1000-1918 and 1938-1944, and of Czechoslovakia from 1918-1938 and 1944-1945. Culturally it was a combination of Galician and Hasidic.

16 Yid: Wedding canopy, under which the Jewish marriage blessings are made.

17 http://video.google.com/videoplay?docid=1622609518319953327\&q=munkatch

18 Frigyesi, Judit, Béla Bartók and Turn-of-the-Century (Budapest, University of California Press, 1998).

19 It should be pointed out that presenters generally have a three-fold objective:

1) To get as large an audience as possible;

2) To vary their programs;

3) To have a good personal profile and public image.

20 World of Music, Arts and Dance.

21 The term "Tropical" was later taken on as the name of a German label, which eventually specialized in Latin American music but then wished to expand its catalogue to include Klezmer music.

22 The term "World Music" was first used in 1982 in France at the Fete de la Musique to designate folk music and eventually all music related to ethnic genres. Following the release in 1986 of Paul Simon's album Graceland the term began to be increasingly used by the industry in order to boost record sales by encouraging crossover appeal. By the mid 1990s the term itself and the dogma behind it became so pervasive that music that was considered traditional was often attached to an image of backwoods, ethno-centric, even racist, especially in Germany, where folk music became branded as the property of the Nazis, thereby making it unpalatable for post-war generations of musicians who were drawn to ethnic music. Germany is the largest country in Europe with the most widespread music industry. It follows that the edicts of the German music industry would have far-reaching effects on the musical economy of Europe and the rest of the world.

23 Email correspondence between Joshua Horowitz and Claus Schreiner of Tropical Records, Germany, 1999.

24 Hannibal Records, Rykodisc HNCD 1373, 1993.

25 Professor Frigyesi was, for a time the life partner of Zev Feldman, the noted scholar and tsimbl player of the duo with Andy Statman.

26 Klezmer Music: Early Yiddish Instrumental Music, The first recordings, 1908-27 from the collection of Dr. Martin Schwartz, Arhoolie Folklyric 7034, 1983. This record was one of the earliest and most seminal sources for performers of Klezmer music during the late 1970s through the 1980s.

27 http://www.passiondiscs.co.uk/rjc/Klezmer01.htm

28 Conversation with Simon Broughton, editor of Songlines Magazine, April 5, 2008.

29 Gardon or Gardonko is a folk cello that is struck with a thick stick, typically played in Gyimes, Transylvania.

30 http://www.jmwc.org/Artists\&PerformingGroups/performers_b.html 
31 Cohen played second violin in my group, Budowitz for a short while in 1997. His cellist, Géza Pénzes, and I met in 1995, (I had been living in Graz Austria since 1984) shortly after I formed Budowitz. At that time Pénzes, who was an active member in the dance house scene with his group Újstílus, played in Di Naye Kapelye, and joined Budowitz in 1996. At that time gigs for Di Naye Kapelye were slim and I offered to help out, occasionally playing with the band and helping Cohen with contracting. The band at that time was struggling to affirm its existence in the Klezmer scene and dabbled in dance house music.

32 Some of the musicians who have been the informants for the dance house movement: Fodor [Neti] and Ferenc Árus from Kalotaszeg; Kodoba Béla and his family from Magyarpalatka; István Ádám [Icsán] from Szék; István Jámbor [Domnezu] and Ferenc Mezei [Csángálo] from Szászcsávás.

33 I was also invited to play at a Budapest festival with the Gypsy cimbalom player Toni Árpád. In 2000 Cohen began to integrate Árpád into their February 2000 tour of Holland and Belgium, and eventually also Mihály Sípos and Péter Éri of Muzsikás.

34 Seth Rogovoy, The Essential Klezmer. http://www.dinayekapelye.com/recmazel.htm

35 Ari Davidow, Klezmer Shack. http://www.Klezmershack.com/articles/davidow/2001 1201_more_hot.html

36 Tim Meyen of Canberra, Australia, leader of the Trio Triplika, "counts Toni Arpad, the septuagenarian Gypsy master from Vajdaszentivany (Voivodeni) who was featured on the Muzsikás album 'the Lost Jewish Music of Transylvania,' among his influential teachers."

37 http://livingtraditions.org

38 The dance house group Fonó (formerly Hegedős), led by Zsolt Kürtösi, has incorporated Klezmer tunes into its repertoire, borrowing both from the Técsői Banda, Budowitz and other sources. Three members of Fonó have been longstanding members of Budowitz and are considered specialists of Klezmer music.

39 The trio Veretski Pass has included some Técsői Banda pieces as well. Its director is Cookie Segelstein, and both Stuart Brotman of Brave Old World and I are part of the trio. These pieces quickly became integrated into the repertoires of other bands in both scenes via bands that learn them from the Técsői recordings. 